\title{
In Search of Key Soil Functions to Assess Soil Community Management for Sustainable Sweet Cherry Orchards
}

\author{
Jennifer Moore-Kucera ${ }^{1}$, Anita Nina Azarenko, Lisa Brutcher, and Annie Chozinski \\ Department of Horticulture, Oregon State University, 4017 Ag Life Sciences Building, Corvallis, OR 97331 \\ David D. Myrold \\ Department of Crop and Soil Science, Oregon State University, 3017 Ag and Life Sciences Bldg., Corvallis, OR 97331

\begin{abstract}
Russell Ingham
Department of Botany and Plant Pathology, Oregon State University, 2082 Cordley Hall, Corvallis, OR 97331
\end{abstract}

Additional index words. organic orchards, soil health, enzyme activities, particulate organic matter, molecular analyses, nematodes, quantitative PCR, ammonia-oxidizing bacteria, soil microbial communities

\begin{abstract}
Organic growers are required to maintain or improve soil chemical, biological, and physical properties and thus need to integrate biological processes into fertility management. However, few guidelines exist for satisfying tree nutrient demands ecologically. Sound nitrogen $(N)$ management is a key component for overall orchard productivity whereas poor $N$ management may result in multiple environmental impacts, including runoff to surface or leaching to groundwater sources. Many growers substitute synthetic inputs with rapid-release, approved $\mathbf{N}$ fertilizers that have little effect on long-term soil health and fertility. The authors seek an alternative approach for synchronizing nutrient availability with tree demand that relies on managing soil biological communities to attain their maximum potential functionality and thus meet tree nutrient demand. This paper outlines a new conceptual framework with which to evaluate a variety of soil functions that are quantified using biological, microbial, and biochemical properties in relation to overall orchard performance. By combining information gathered from soil faunal indices (nematode community structure and diversity analyses) with data obtained by biochemical and microbial analyses of the soil samples, a new, in-depth view of soil communities and their response to management practices will be obtained. As a result, a better understanding of the effects of differing management practices on soil fertility and community structure will be gained. This approach is currently being investigated by our group in organic and integrative sweet cherry orchards. Our goal is to determine which soil parameters may be used to help orchardists optimize soil health while maintaining orchard productivity. Furthermore, we wish to validate a number of assumptions that are commonly made regarding each soil parameter tested across multiple management, soil, and climate types.
\end{abstract}

Orchard floor management (OFM) greatly affects tree health and performance by altering nutrient and water dynamics. As sustainable agriculture practices become the convention, there is a growing need for decision tools that can assist land managers in determining which soil tests they should use and which best management practice recommendations they should adopt. A well-defined, multiobjective decision-making framework is needed to evaluate management decisions with regard to their sustainability relative to economic and environmental goals (Andrews et al., 2002).

A major goal of OFM is to synchronize nutrient availability with crop demand while minimizing nutrient losses. Nitrogen $(\mathrm{N})$ management, in particular, is a focus in agricultural systems because of its importance to crop health and yields, and because, if mismanaged, numerous environmental problems may result. In orchards, the $\mathrm{N}$ status of trees affects many physiological responses, such as overall tree growth, flowering, fruit set, fruit growth, and fruit quality (size, color, firmness, degree Brix, and percent cracking). Synchronizing nutrient availability with tree demand is essential to ensure optimal tree health and performance, and to minimize off-site nutrient losses via leaching, erosion, or denitrification pathways. Nitrogen requirements change depending upon tree

${ }^{1}$ To whom reprint requests should be addressed; e-mail Jennifer.kucera@hort.oregonstate.edu. growth stage and can increase by an order of magnitude after trees become full grown (Azarenko, unpublished data). Furthermore, for cherry trees, $\mathrm{N}$ application must occur before leaf senescence in the fall if $\mathrm{N}$ is to be available in the following spring for budbreak, flower development, and fruitlet growth (Sanchez et al., 1995). Nitrogen applied postharvest is distributed to the roots and only becomes available in spring after budbreak of the next growing season (Azarenko, unpublished data). Precise timing of adequate amounts of $\mathrm{N}$ also will result in maximal tree uptake with little to no $\mathrm{N}$ reaching ground or surface waters.

Improving tree performance via optimal fertility management is a common goal among conventional and organic growers. In addition, improving soil health is a requirement for organic growers [ $\$ 205.203$ a (National Organic Program, 2002)]. Soil health has been defined as the "capacity of a soil to function within ecosystem boundaries to sustain biological productivity, maintain environmental quality, and promote plant anchorage and animal health" (Doran et al., 1996). Implied soil functions include the capacity to supply nutrients, retain optimal water content, support soil food webs, recycle nutrients, maintain microbial diversity, remediate pollutants, and suppress plant pathogens. Farm management practices that enhance soil health include organic matter addition and conservation and synthetic pesticide reduction or elimination; many of these practices are routinely used in organic farm- ing. Nitrogen is a nutrient of particular concern when considering overall soil health because it is one of the most frequently applied nutrients, and improper management could lead to pollution of freshwater systems and potentially can increase pests and postharvest disorders. Often there is a lack of appropriate nutrient management recommendations and management guidelines pertinent to organic systems. In general, many organic orchardists substitute synthetic inputs with rapid-release forms of approved, "palletized" fertilizers made of various fish and poultry by-products. This approach to achieve fertility appears to be lacking given that organic growers are required to "manage crop nutrients and soil fertility through rotations, cover crops, and the application of plant and animal materials" to meet certification requirements [\$205.203b (National Organic Program, 2002)].

The soil-microbial-plant system, providing it is managed properly, holds great potential for meeting tree nutrient demands ecologically and efficiently. This is because more than $90 \%$ of all nutrients pass through the microbial biomass to higher trophic levels (Kennedy, 1995). Through the integrated functions of the soil biological community, nutrients are converted from organic materials into plant-available forms. The composition, activity, and biomass of soil microbial communities have been shown to be influenced by management practices such as tillage (Deng and Tabatabai, 1996a, b, 1997; Ekenler and Tabatabai, 2003), cropping 
system (Acosta-Martinez et al., 2003; Deng et al., 2000; Klose and Tabatabai, 2000; Moore et al., 2000), manure addition (Acosta-Martinez and Harmel, 2006; Deng et al., 2006) groundcover management in orchards (Yao et al., 2005), fertilization in orchards (Kramer et al., 2005; Reganold et al., 2001), and by the choice between conventional and organic production (Mader et al., 2002; Monokrousos et al., 2006; van Diepeningen et al., 2006). Likewise, organisms at higher soil trophic levels, such as nematodes, show similar responses (Forge et al., 2003; Ingham, 1985; Neher, 1999; Neher and Olson, 1999). Because management decisions affect soil microbial and faunal populations, and because soil microbial and faunal populations have been shown to affect soil nutrient cycling, management decisions therefore influence the soil's ability to meet tree nutrient demand.

By using mulches, compost, animal manure, cover crops such as green manures, or by mowing and transferring groundcover materials between trees ("mow and blow"), it may be possible to develop a farming system that will use inherent soil fertility via enhanced nutrient cycling by the resident soil biological community. However, it is unclear how sustainable these practices are from a practical and economical viewpoint.

Recent orchard studies have focused on only the faunal component of soil communities and their relationship to $\mathrm{N}$ mineralization rates in an attempt to characterize the biological community response to management practices (Forge et al., 2003). Although the soil microbial community plays a central role in nutrient cycling, few studies have examined the effects of OFM practices on soil microbial communities (Goh et al., 2001; Oved et al., 2001; Rutto et al., 2002; Yao et al., 2005). Therefore, our approach is to investigate OFM systems in relation to soil food web structure and function with a primary focus on the status and dynamics of $\mathrm{N}$ fertility. Soil food web structure will be characterized by nematode population concentrations and community indices, and by molecular analyses of bacterial and fungal communities. Soil function will be characterized by assessing biochemical pathways, such as enzyme potentials, $\mathrm{N}$ mineralization, and particulate organic matter (POM) dynamics.

There exists a variety of tools used to evaluate the effects of land management practices on soil health. These include analysis of soil organic matter (SOM) concentrations, nematode faunal composition (Ferris et al., 2001), enzyme activities (Acosta-Martinez et al., 2003; Bandick and Dick, 1999; Klose et al., 2006), and microbial community composition (Acosta-Martinez and Harmel, 2006). Little research, however, has used a multilevel approach to examine these soil biological community assessments in combination with soil chemical and abiotic controls (e.g., soil moisture and temperature dynamics), and the relationships of these factors to OFM and overall orchard health. Moreover, we know of no such study focusing on sweet cherry orchards. We feel that by integrating the disciplines of soil chemistry, biology, microbiology, and physics; plant physiology; nematology; and agroeconomics, we will be able to identify those soil properties that are the most sensitive to OFM and can best predict nutrient demand and overall orchard health. Therefore, the long-term goal of this research effort is to understand and identify which group of the soil parameters tested can be used to establish a soil health index applicable to sweet cherry orchards. The focus of our research is on $\mathrm{N}$ management, but we also intend to use economic and orchard performance goals to assess these potential indicators. This index will provide valuable information to help orchardists select best management practices for an economically and environmentally sustainable orchard.

The purpose of this article is to provide an overview of the soil characteristics we intend to study to develop a soil health index and a discussion of their functional importance in

Table 1. Soil biological, chemical, and physical properties to be measured and included within the conceptual framework shown in Fig. 2.

\begin{tabular}{lc}
\hline Soil property & Methodology \\
\hline $\begin{array}{l}\text { Biological analyses } \\
\text { Nematode composition }\end{array}$ & $\begin{array}{c}\text { Baerman pan technique (7-d incubation) as described } \\
\text { by Ingham (1994) }\end{array}$ \\
$\begin{array}{l}\text { Fungivores } \\
\text { Bacteriovores }\end{array}$ & \\
$\begin{array}{l}\text { Plant parasitic } \\
\text { Omnivores }\end{array}$ & \\
Predators & \\
Enzyme assays & All enzyme assays will follow the methodology as \\
& described by Tabatabai (1994) except for N-acetyl- $\beta$-D- \\
& glucosaminidase, which will be determined according to \\
the method of Parham and Deng (2000)
\end{tabular}

Arylsulfatase

Acid and alkaline phosphatase

$\mathrm{N}$-acetyl- $\beta$-D-glucosaminidase

Molecular analyses

Ammonia-oxidizing bacteria

Denitrifying bacteria

Actinomycetes

Total bacteria

Total fungi

Chemical analyses

$\mathrm{pH}$, organic matter, $\mathrm{P}, \mathrm{K}, \mathrm{Mg}$,

$\mathrm{Ca}, \mathrm{Na}, \mathrm{CEC}, \mathrm{NO}_{3}^{-}, \mathrm{SO}_{3}^{-}, \mathrm{Zn}$,

$\mathrm{Mn}, \mathrm{Fe}, \mathrm{Cu}, \mathrm{B}, \mathrm{Cl}, \mathrm{NH}_{4}{ }^{+}$, and

Kjeldahl N

$\mathrm{N}$ mineralization potential

Total C and $\mathrm{N}$

Particulate organic matter $\mathrm{C}$ and $\mathrm{N}$ (POM-C and POM-N)

Soil solution for inorganic $\mathrm{N}$

Physical analyses

Bulk density

Water-stable aggregates

Infiltration rate

Soil temperature (at LB only)

Horz et al. (2000, 2004)

Braker et al. (1998)

Fierer et al. (2005)

Yu et al. (2005)

Samples sent to A \& L Laboratories (Portland, OR)

$\mathrm{N}$ minimum potential determined by anaerobic incubation as described by Keeney and Bremner (1966)

Total $\mathrm{C}$ and $\mathrm{N}$ determined by combustion using a LECO CNS analyzer (LECO Corp., St. Joseph, MI)

POM-C and POM-N determined according to Marriott and Wander (2006b)

Soil solution using suction lysimeters (Prenart Equipment, Frederiksberg, Denmark) and analyzed for nitrate $\mathrm{N}$ and ammonium $\mathrm{N}$

Core method (rings of a given volume are inserted into soil, weighed, dried, and reweighed to determine the amount of soil in grams per cubic centimeter

Water-stable aggregates and infiltration rates methodologies have yet to be confirmed

Soil temperature and moisture monitored by thermocouples and at ECH2O probes (Decagon, Pullman, WA) at three depths

Soil moisture (at LB only)

LB, Lewis Brown Research Farm in Corvallis, OR; POM-C, particulate organic matter C; POM-N, particulate organic matter $\mathrm{N}$. 
Horz et al., 2000, 2004; Ingham, 1994; Keeney and Bremner, 1966; Marriott and Wander 2006b). Soil organic matter (SOM) is one of the most commonly measured soil quality constituents. It is comprised of multiple fractions ranging from readily decomposable compounds that can be a nutrient source for microbes and plants to recalcitrant or stable materials. As a whole, these fractions are responsible for varied functions in the soil system that improve soil quality. Unfortunately, whole SOM concentrations tend to change slowly unless extremely large amounts of organic amendments are added to the soil. Consequently, researchers are investigating sensitive or more responsive SOM fractions that more readily reflect the effects of management and are better indicators of short-term soil fertility dynamics (Bolinder et al., 1999; Magid et al., 1996; Wander, 2004; Yakovchenko et al., 1998). Recent research has focused on the active SOM pools, or on those fractions involved in microbial processes, because nutrient cycling is largely driven by microbial functioning. These fractions are considered more responsive to changes in $\mathrm{C}$ inputs compared with measurements using total SOM.

Particulate organic matter is one of these fractions. Based on field studies, POM holds promise as a proxy for the biologically active pool of SOM and as a fertility index (Elliott et al., 1994; Marriott and Wander, 2006a). An additional fertility index, soil microbial biomass, has often been used for similar reasons. However, unlike microbial biomass assays that require immediate analysis using fieldmoist soil, POM is analyzed using air-dried samples and thus does not require immediate analysis. Additionally, it is a relatively simple procedure, making this test particularly promising for adoption in commercial soil testing laboratories. Particulate organic matter is operationally defined as sand-size organic material consisting of fine roots and large organic debris (Cambardella and Elliott, 1992). It is extracted from the soil using a dispersing solution and sieves. Particulate organic matter represents young (turnover time of 5-25 years) biologically and physically active organic matter (Yakovchenko et al., 1998). The amount of $\mathrm{C}$ and $\mathrm{N}$ associated with POM has been shown to predict the amount of $\mathrm{N}$ that can be mineralized (made available to plants) as crop residues are added to soils (Biederbeck et al., 1994; Gregorich et al., 2006; Magid and Kjaergaard, 2001; Marriott and Wander, 2006a; Yakovchenko et al., 1998).

Soil biological activity is also studied using soil enzyme potentials. Soil enzymes are responsible for biochemical reactions involved in numerous important functions related to fertility. Enzymes released by plant roots and microorganisms catalyze the breakdown of complex organic material bound in plant residues into bioavailable forms that subsequently may be assimilated by plants (Tabatabai, 1994). Although enzymes may originate from different sources, including bacteria, fungi, plants and animals, the soil microorganisms are considered the major source because of their large biomass, high metabolic activity, and short lifetimes (Tabatabai and Dick, 2002). Significant correlations have been shown between enzyme activities and $\mathrm{N}$ mineralization potential (Deng et al., 2000; Ekenler and Tabatabai, 2004). Also, enzyme activity potentials have proved useful as sensitive indicators of land management changes and have been proposed as soil quality indicators (Bandick and Dick, 1999; Dick, 1994; Knight and Dick, 2004).

Because soil microbial functional diversity encompasses several metabolic activities, Nannipieri et al. (2002) proposed that a suite of enzyme assays focusing on multiple soil functions be used over a study that assesses a single enzyme activity. Using this approach in combination with multivariate statistics may prove useful in evaluating, for example, how farm management decisions affect microbial functional diversity and, thus, biochemical processes and soil quality status. Therefore, we have chosen five enzyme assays involved in $\mathrm{C}$ ( $\beta$-glucosidase), $\mathrm{N} \quad[\mathrm{N}$-acetyl- $\beta$-D-glucosaminidase (NAGase)], S (arylsulfatase), and P (acid and alkaline phosphomonoeseterases) nutrient cycling. We chose these particular enzymes primarily because of their importance in nutrient cycling and organic matter decomposition and secondarily because the methodologies are based on the same principles for all five assays (Parham and Deng, 2000; Tabatabai, 1994). These factors, coupled with the relatively simple and inexpensive analyses using chemicals of low toxicity, increase the potential that these assays can be adopted by commercial soil testing facilities.

More specifically, $\beta$-glucosidase was chosen because it regulates the rate-limiting step of cellulose degradation ( $\mathrm{C}$ cycle) and releases low-molecular weight sugars that are important energy sources for soil microorganisms (Tabatabai, 1994). It has been used as a sensitive indicator of changes in soil quality resulting from land management changes and has been proposed as a soil quality indicator in fertility and crop rotation studies (Bandick and Dick, 1999). The enzyme N-acetyl- $\beta$-D-glucosaminidase (a.k.a. NAGase or $\beta$-glucosaminidase) facilitates the breakdown of chitooligosaccharides into amino sugars. This is an important function in soils because chitin is the second most abundant biopolymer on earth, and amino sugars serve as an important "mineralizable" N source (Ekenler and Tabatabai, 2002). Therefore, this enzyme is important in both $\mathrm{C}$ and $\mathrm{N}$ cycling in soils, has been shown to correlate with $\mathrm{N}$ mineralization indices (Ekenler and Tabatabai, 2002), and is sensitive to land management changes (AcostaMartinez et al., 2003). Arylsulfatase is important in releasing plant-available $\mathrm{SO}_{4}$ from organic sulfate esters (Tabatabai, 1994). Because only fungi contain ester sulfates (the substrate for arylsulfatase), arylsulfatase activity may also serve as an indirect indica- tor of fungi (Bandick and Dick, 1999). Acid and alkaline phosphatases were chosen because, like $\mathrm{S}$, the majority of soil organic $\mathrm{P}$ is bound as ester phosphates in complex organic compounds (Anderson, 1980) and must be converted by phosphatases into bioavailable forms. Phosphorus nutrition, although not typically limiting in Oregon orchards, is especially important in the establishment of new trees. We included both acid and alkaline forms because soil $\mathrm{pH}$ affects their activities and because most orchards we study are near-neutral $\mathrm{pH}$.

Although microorganisms are the primary source of enzymes released in soil, the actual microorganisms responsible for their release and subsequent biochemical functions are largely unknown. Current estimates suggest that 10,000 different prokaryotic species exist per gram soil (Torsvik et al., 2002); however, less than $1 \%$ of microbes observed under a microscope have been characterized using classical culture-dependent methods (Torsvik et al., 1990). Because it is not practical to attempt to characterize this immense diversity, we will take a more targeted approach and use rapid and relatively inexpensive molecular methods to quantify the abundance and describe the composition of the microbial community at several levels of specificity. Abundances will be measured using the quantitative polymerase chain reaction ( $\mathrm{qPCR}$ ) and a fingerprint of microbial community composition will be obtained by terminal restriction fragment length polymorphism analysis. As described by $\mathrm{Yu}$ et al. (2005), these methods can be combined to obtain a quantitative picture of microbial communities.

These molecular methods require the extraction of DNA from soil, which can be readily done using commercial kits. For qPCR, DNA extracted from a soil sample is amplified via the PCR in the presence of a fluorescent reporter molecule. This allows the quantity of PCR products generated at each step of the reaction to be monitored. From this information, the original number of copies of the target gene or sequence can be calculated (Fierer et al., 2005, Okano et al., 2004). Terminal restriction fragment length polymorphism can then be performed on the products of the qPCR reaction. First, the products are cleaved with restriction enzymes. Then, if a fluorescently labeled primer was used during the original qPCR reaction, the terminal fragments produced by the restriction can be detected as they are separated according to size by capillary electrophoresis. The banding pattern created by electrophoresis, or the "community fingerprint," has been used to represent the total richness and relative abundance of organisms within the target population (Avaniss-Aghajani et al., 1996; Liu et al., 1997; Marsh, 1999).

We will use this combination of techniques to examine the populations of total soil fungi and total soil bacteria as well as three subcommunities of bacteria with significant roles in the cycling of N. These subcommunities are the actinomycetes, which play an 
important role in the breakdown of organic matter through the degradation of cellulose, lignin, chitin, and other recalcitrant polymers (Heuer et al., 1997; Krsek and Wellington, 2001); the ammonia-oxidizing bacteria, which control ammonia oxidation, the ratelimiting step in the process of $\mathrm{N}$ cycling (Prosser, 1989); and the denitrifying bacteria, a nonphylogenetic functional group that converts soluble nitrate to gaseous $\mathrm{N}$, thus removing plant-available $\mathrm{N}$ from the soil system (Tiedje et al., 1982). By combining the molecular information about specific and general microbial populations with enzymatic information, soil food web analysis via nematode populations, and soil chemical properties under different management systems, we hope to be able to link microbial groups with their activities and functions within this ecosystem (Torsvik and Ovreas, 2002).

Soil microorganisms are the primary decomposers in the soil food web and occur at the second trophic level (the first is photosynthetic plants and microbes). Their populations affect and are affected by nematodes that prey upon bacteria, fungi, and plant roots. When nematode populations are low, nematode feeding can actually stimulate microbial or plant growth via the release of nutrients. Nematodes contribute to $\mathrm{N}$ mineralization via grazing on microbes and releasing $\mathrm{NH}_{4}^{+}$or storing $\mathrm{N}$ in their biomass (Griffiths, 1994; Ingham, 1985). At high nematode densities, plant productivity and mycorrhizal associations can be affected negatively. Predation by nematodes on bacterial and fungal populations may control the balance of their numbers in soil. Therefore, nematode community structure (the type and amount of various nematodes) plays an important role in mineralization and immobilization pathways of organic material (Neher, 2001) and has been proposed as a useful indicator of substrate quality and nutrient release (Griffiths, 1994; Ingham, 1985).

Additions of organic amendments of differing qualities have been shown to alter nematode community composition (Ferris and Matute, 2003). Ferris and Matute showed that bacterivorous (bacterial-feeding) nematodes were stimulated with additions of highquality organic material (Lucerne), whereas fungivorous nematodes were enhanced with the addition of lower quality substrates (wheat straw). Forge et al. (2005) showed that after 1 year of manure application, the abundance of bacterivorous and fungivorous nematodes was increased to levels equivalent to those with 6 years of continuous manure application. Numerous studies also have shown enhanced $\mathrm{N}$ mineralization potential and microbial biomass turnover with increased grazing by bacterial- and fungalfeeding nematodes (Griffiths, 1994; Ingham, 1985). More recently, Forge et al. (2003) found a positive correlation between leaf $\mathrm{P}$ concentrations from apple trees and the abundance of enrichment opportunistic nematodes.
Numerous interpretations of nematode community composition have been used as indicators of soil ecosystem status (Ferris et al., 2001; Forge et al., 2005; Neher, 2001). Ferris et al. (2001) developed a model to evaluate soil food web structure, enrichment, and decomposition channels using nematode faunal analysis. They also proposed different features of nematode communities that would arise under various agricultural farming systems [Fig. 1; adapted from Ferris et al. (2001)]. In the work by Ferris et al. (2001), two indices, an enrichment index (EI) and a structural index (SI), were used to determine the extent to which the nematode community has shifted toward relative dominance by taxa with enrichment opportunist ecological characteristics (EI) and the degree of complexity or "connectivity" of nematodes in the soil food web (SI). An additional index, the channel index (CI), provides information about decomposition pathways by examining the ratio of fungalto bacterial-feeding nematodes. A high CI value is indicative of a greater dominance of a fungal decomposer food web (Ferris et al., 2001). A high EI value is often associated with an N-enriched system with a comparatively low soil C-to-N ratio. A higher SI value is associated with a maturing or well-structured food web and with systems that are less disturbed or are undisturbed (such as those found in organic, no-till, perennial agroecosystems or in native forest ecosystems).

According to Ferris et al. (2001), the "basal" point, located in the lower left corner of quadrat D in Fig. 1, is representative of systems that are stressed, with depleted resources and a degraded food web. Working clockwise from this point, systems become more enriched with low C-to-N ratios and maturing food webs. Moving along the $\mathrm{x}$-axis, systems transition from bacterial dominance to fungal dominance. Systems dominated by bacterivores are found in the upper left quadrat (A), whereas fungivores more often are found in the two lower quadrats (C and D). The authors suggested examples of ecosystems associated with each quadrat. They placed conventional annual crops in the lower left quadrat (D); managed grasslands or pastures and organic annual crops in quadrats $\mathrm{A}$ and $\mathrm{B}$; natural, undisturbed systems in quadrat $C$; and perennial crops in quadrats $\mathrm{B}$ or $\mathrm{C}$, depending upon management (Fig. 1).

To help determine which of the soil properties that we are monitoring are the most sensitive to OFM practices, we have expanded the model of Ferris et al. (2001) to include our hypothesis of where microbial population dynamics and activities will cluster (Fig. 2) We have incorporated the likely responses of soil microbial populations (represented by the five enzyme activities and molecular biomarkers) to the quality and quantity of $\mathrm{C}$ and $\mathrm{N}$ compounds (as indicated by POM-C, POM-N, and POM C-to-N ratios) provided by mulches, manure, compost, green manures, or straw used in a "systems approach" to orchard management. The circled area in Fig. 2 is the proposed targeted area for a best management system given the test parameters chosen.

We hypothesize that within the managed cherry orchards of our study, those that rely on synthetic fertilizers and organic residues exclusively supplied by leaf fall (tree residues) will be characterized by a low SI value, low biological diversity, and low complexity of $\mathrm{N}$ - and $\mathrm{C}$-containing molecules, and will therefore be bacterial dominated (and thus, have a greater bacterivorous nematode population) with lower relative enzymatic activities. This is in contrast to a system with added organic materials, such as bark mulch, straw, or compost, that likely would support greater fungal and fungi-feeding nematode populations.

\section{STUDY DESIGN TO TEST OUR MODEL}

To test our hypothesis, we have a twotiered study design. The first part is an analysis of the effects of two organic treatments

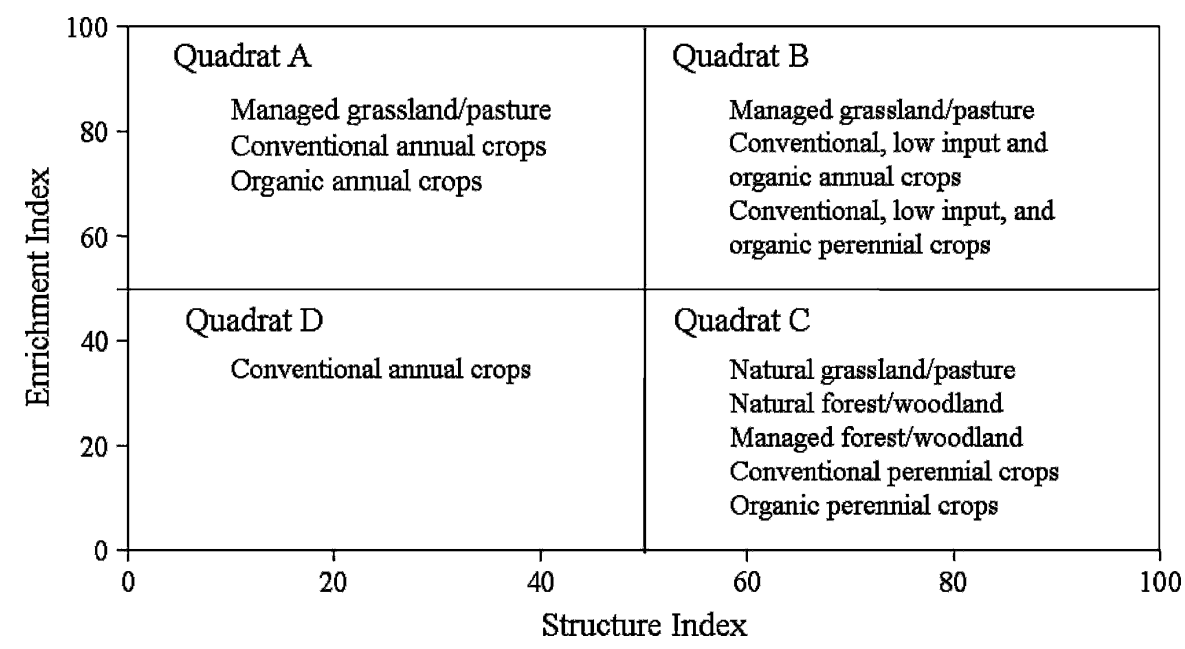

Fig. 1. Proposed conditions of faunal profiles of nematode communities as influenced by agricultural farming systems. Adapted from Ferris et al. (2001). 


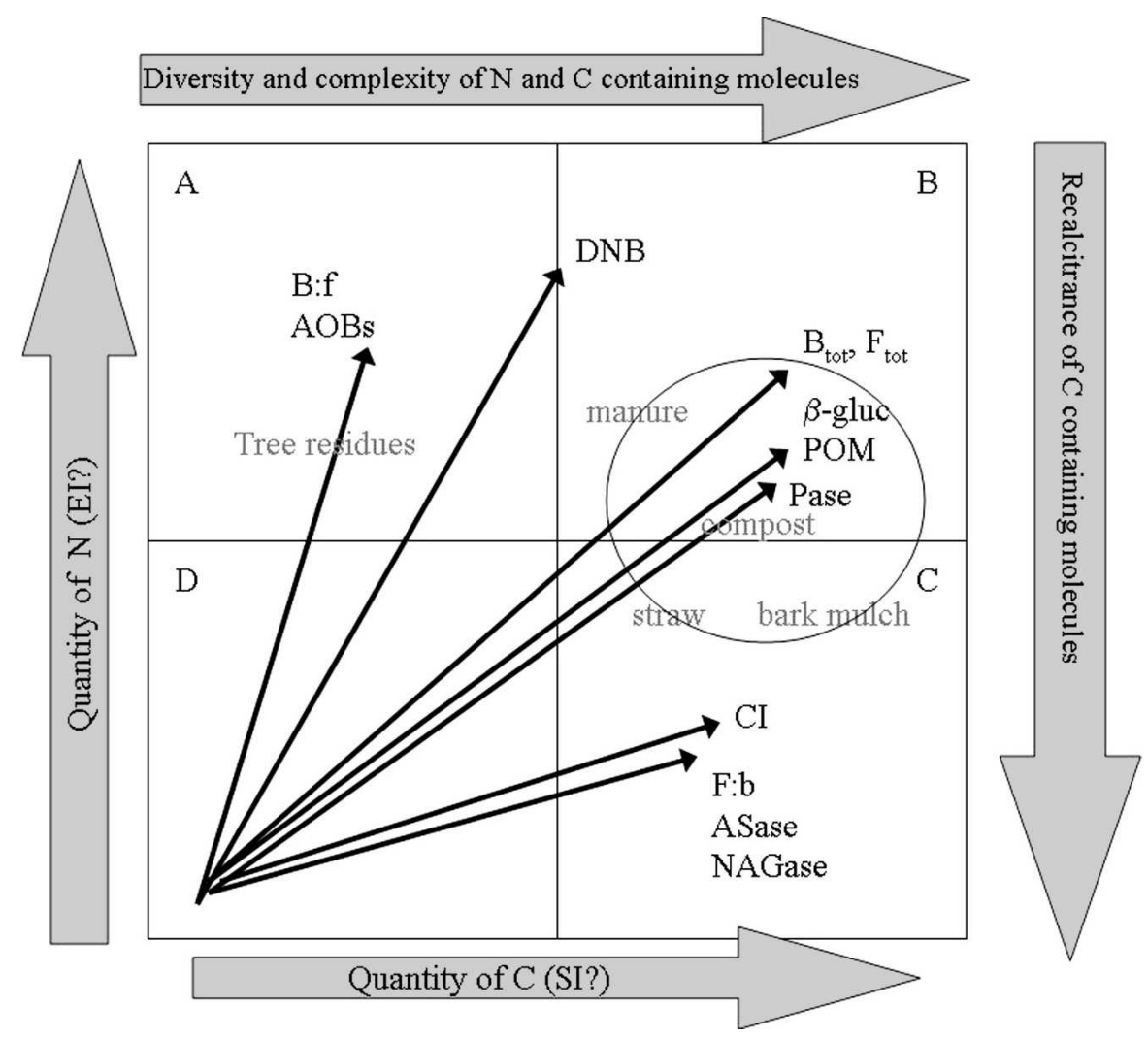

Fig. 2. Conceptual framework as related to the nematode faunal profile model proposed by Ferris et al. (2001) for soil biological properties and orchard performance with varied orchard floor management systems. See text for details. b or B, bacteria, where relative amounts are lesser for lowercase b and more for uppercase B; f or F, fungi; AOB, ammonia-oxidizing bacteria; DNB, denitrifying bacteria; $\beta$-gluc, $\beta$-glucosidase; Pase, phosphatase; ASase, arylsulfatase; NAGase, N-acetyl- $\beta$-D-glucosaminidase; POM, particulate organic matter; SI, structure index; EI, enrichment index; CI, channel index for nematodes.

on trees, soils, and profitability during orchard establishment at two experimental orchards [Lewis Brown Research Farm in Corvallis, OR (LBF), and the mid-Columbia Agricultural Research and Extension Center in Hood River, OR (HR)]. The second part will characterize soil health in 13 mature commercial orchards throughout Oregon. These commercial orchards were selected to evaluate how OFM strategies that vary according to climate, soil types, and management history affect the tested variables. In this fashion we expect to determine whether the soil health index that we establish is valid across these variable cherry orchards. Additionally, on a more basic level, we wish to test a number of assumptions that are made regarding the application of a given soil variable. These include the following. First, if POM represents the biologically active fraction of whole soil organic matter, then other tests of biological processes such as enzymatic activities should increase as concentrations of POM increase. Enzymatic activities such as $\beta$-glucosidase, cellobiohydrolase, NAGase, and phosphatase have been shown to be most prevalent in the POM fractions (Allison and Jastrow, 2006) in tallgrass prairies, but no work on this topic has been conducted in orchard systems. Second, if a land management decision ments) of fertility management: input substitution (IS) and whole system management (Syst). The IS method is characterized as meeting nutrient needs by the substitution of rapid-release forms of organically approved, pelletized fertilizers made of fish and poultry by-products in place of synthetic fertilizers. Weed control is primarily obtained by the use of landscape cloth. The second method, Syst, relies on the application of organic nutrient sources to fuel the soil microbial community. This will be accomplished with the additions of mulches, compost, and green manures (leguminous-grass mixtures planted in the alleyways that will be mowed and the residue of which will be placed within tree rows). The microorganisms, through mineralization processes, will be the primary nutrient supplier. The composition, activity and biomass of soil communities are known to be influenced by management practices. For example, the addition of bark mulch, straw, or compost, with $\mathrm{C}$-to-N ratios ranging from $30 \mathrm{C}: 1 \mathrm{~N}$ to $300 \mathrm{C}: 1 \mathrm{~N}$, elicits a distinct response by bacteria and fungi to break down these amendments. Under Syst management, a 4inch layer of bark or straw mulch was applied within tree rows at LBF and HR respectively. Additionally, weed management is obtained via in-row cultivation. Drip irrigation systems were installed at both sites to conserve water. Trees have been pruned to manipulate vegetative and reproductive growth, and branch training continues.

At LBF and HR, overall tree performance will be evaluated by growth (as measured by trunk cross-sectional area), leaf chemical analysis, yield, fruit quality tests, and disease incidence. A full cost-benefit analysis of the two management treatments at the research plots will be conducted. Additionally, the effects of IS and Syst managements on soil temperature (using thermocouples) at 15- and $30-\mathrm{cm}$ depths, and volumetric water content (using ECH2O probes; Decagon, Pullman WA) at 15-, 30-, and 90-cm depths are being intensively monitored at LBF. These soil parameters are important for nutrient supply and uptake because the timing of soil warming in spring affects tree performance. This impact may be beneficial if earlier soil warming in spring leads to earlier bloom and fruit production. However, if soils warm to soon in spring, floral buds become more susceptible to freezing injury. Warm soil temperatures also result in increased root activities of weeds, which may compete with tree roots for nutrients and water. Soil solution chemistry using suction lysimeters (Prenart Equipment, Denmark) with a focus on nitrate $\mathrm{N}$ status also will be monitored at 15 and $30 \mathrm{~cm}$, which is where the majority of tree roots are located, as well as at $90 \mathrm{~cm}$ to determine the amount of $\mathrm{N}$ leaching beyond the rooting zone.

We also are measuring the same suite of soil biological and chemical properties described for LBF and HR (Table 1) in eight mature commercial orchards in different regions of Oregon (Table 2). In addition to LBF and HR, four additional orchards are 
Table 2. List of orchard floor managements, soil series, location, average annual precipitation, and average maximum and minimum temperatures at the two experimental orchards ${ }^{2}$ and eight mature commercial orchards used in the study.

\begin{tabular}{|c|c|c|c|c|c|c|c|}
\hline $\begin{array}{l}\text { Orchard Floor } \\
\text { Management }\end{array}$ & Soil series & Texture & Town & County & $\begin{array}{l}\text { Average annual } \\
\text { precipitation } \\
(\mathrm{cm})\end{array}$ & $\begin{array}{c}\text { Average maximum } \\
\text { temperature } \\
\left({ }^{\circ} \mathrm{C}\right)\end{array}$ & $\begin{array}{c}\text { Average minimum } \\
\text { temperature } \\
\left({ }^{\circ} \mathrm{C}\right) \\
\end{array}$ \\
\hline Organic $^{z}$ & van Horn & Fine sandy loam & Hood River & Hood River & 76.2 & 16.2 & 4.5 \\
\hline Organic & van Horn & Loam & Mosier & Wasco & 76.2 & 16.2 & 4.5 \\
\hline Organic & Nekia & Silty clay loam & Sweet Home & Linn & 131.8 & 17.3 & 5.3 \\
\hline Int (straw) & Chenowith & Loam & The Dalles & Wasco & 36.6 & 18.7 & 6.4 \\
\hline Int (control vs. straw) & Chenowith & Loam & The Dalles & Wasco & 36.6 & 18.7 & 6.4 \\
\hline Organic & Willamette & Silt loam & Corvallis & Benton & 104.1 & 17.2 & 5.4 \\
\hline Organic & Chehalis & Silty clay loam & Junction City & Lane & 102.6 & 16.9 & 5.6 \\
\hline
\end{tabular}

${ }^{2}$ Research farms.

Each row represents a different orchard. Climate data were obtained from nearby weather stations (http://www.wrcc.dri.edu/summary/climsmor.html). Soil series information may be obtained from http://soils.usda.gov/technical/classification/osd/index.html.

Int, integrative.

certified organic, whereas integrative management practices are used in the other four. Two of these integrative orchards have onfarm trials where a comparison between the addition of straw and a conventional herbicide strip will be evaluated. Using all 10 orchards enables us to test our hypotheses across multiple orchards that vary in OFM, soil type, climate, and management history (Table 2).

Our first full year of sampling was completed in Nov. 2006. Our preliminary nematode results suggest that the model proposed by Ferris et al.,(2001) reveals differences between management practices. We also have evidence that POM-C and POM-N concentrations were positively correlated with $\mathrm{N}$ mineralization potential $(r>0.47, \mathrm{~N}$ $=98, P<0.0001)$ and with the sum of nitrate $\mathrm{N}$ and ammonium $\mathrm{N}(r>0.65, \mathrm{~N}=98, P<$ 0.0001 ), indicating that POM holds potential as a soil fertility index in cherry orchards (data not shown). Further testing will confirm whether these trends continue over time and whether the soil tests that provide the best soil health index are the same in the eight mature orchards with contrasting properties.

We plan to determine the seasonal variability of our sampling protocol and how it may be modified to reduce, potentially, analysis costs and labor. To develop a soil health index, we will examine and compare a weighted soil quality indexing technique using the work by Glover et al. (2000) as a template, along with the methodology proposed by Andrews et al. (2002) to evaluate soil properties and to develop a minimum data set for this index. Our overall goal is to recommend which soil analyses in sweet cherry orchards are most relevant as decision tools for growers, extension agents, and researchers to monitor how land management changes will affect soil health, tree performance, and economic profitability.

\section{Literature Cited}

Acosta-Martinez, V. and R.D. Harmel. 2006. Soil microbial communities and enzyme activities under various poultry litter application rates. J. Environ. Qual. 35:1309-1318.
Acosta-Martinez, V., S. Klose, and T.M. Zobeck. 2003. Enzyme activities in semiarid soils under conservation reserve program, native rangeland, and cropland. J. Plant Nutr. Soil Sci. 166:699-707.

Allison, S.D. and J.D. Jastrow. 2006. Activities of extracellular enzymes in physically isolated fractions of restored grassland soils. Soil Biol. Biochem. 38:3245-3256.

Anderson, G. 1980. Assessing organic phosphorus in soil, p. 411-431. In: F.E. Khasawneh, E.C. Sample, and E.J. Kamprath (eds.). The role of phosphorus in agriculture. American Society of Agronomy, Madison, WI.

Andrews, S.S., D.L. Karlen, and J.P. Mitchell. 2002. A comparison of soil quality indexing methods for vegetable production systems in northern California. Agr. Ecosyst. Environ. 90:25-45.

Avaniss-Aghajani, E., K. Jones, A. Holtzman, T Aronson, N. Glover, M. Boian, S. Froman, and C.F. Brunk. 1996. Molecular technique for rapid identification of mycobacteria. J. Clin. Microbiol. 34:98-102.

Bandick, A.K. and R.P. Dick. 1999. Field management effects on soil enzyme activities. Soil Biol. Biochem. 31:1471-1479.

Biederbeck, V.O., H.H. Janzen, C.A. Campbell, and R.P. Zentner. 1994. Labile soil organic matter as influenced by cropping practices in an arid environment. Soil Biol. Biochem. 26:1647-1656.

Bolinder, M.A., D.A. Angers, E.G. Gregorich, and M.R. Carter. 1999. The response of soil quality indicators to conservation management. Can. J. Soil Sci. 79:37-45.

Braker, G., A. Fesefeldt, and K.P. Witzel. 1998. Development of PCR primer systems for amplification of nitrite reductase genes (nirK and nirS) to detect denitrifying bacteria in environmental samples. Appl. Environ. Microbiol. 64:3769-3775.

Cambardella, C.A. and E.T. Elliott. 1992. Particulate soil organic-matter changes across a grassland cultivation sequence. Soil Sci. Soc. Amer. J. 56:777-783.

Deng, S.B., J.M. Moore, and M.A. Tabatabai 2000. Characterization of active nitrogen pools in soils under different cropping systems. Biol. Fertil. Soils 32:302-309.

Deng, S.P., J.A. Parham, J.A. Hattey, and D. Babu. 2006. Animal manure and anhydrous ammonia amendment alter microbial carbon use efficiency, microbial biomass, and activities of dehydrogenase and amidohydrolases in semiarid agroecosystems. Appl. Soil Ecol. 33:258-268.
Deng, S.P. and M.A. Tabatabai. 1996a. Effect of tillage and residue management on enzyme activities in soils. 1. Amidohydrolases. Biol. Fert. Soils 22:202-207.

Deng, S.P. and M.A. Tabatabai. 1996b. Effect of tillage and residue management on enzyme activities in soils. 2. Glycosidases. Biol. Fert. Soils 22:208-213.

Deng, S.P. and M.A. Tabatabai. 1997. Effect of tillage and residue management on enzyme activities in soils. 3. Phosphatases and arylsulfatase. Biol. Fertil. Soils 24:141-146.

Dick, P.P. 1994. Soil enzyme activities as indicators of soil quality. In: J.W. Doran, D.C. Coleman, D.F. Bezdicek, and B.A. Stewart (eds.). Defining soil quality for a sustainable environment SSSA Special Publication No. 35. Soil Science Society of America, Madison, WI.

Doran, J.W., M. Sarrantonio, and M.A. Liebig. 1996. Soil health and sustainability. Adv. Agron. 56:1-54.

Ekenler, M. and M.A. Tabatabai. 2002. Betaglucosaminidase activity of soils: Effect of cropping systems and its relationship to nitrogen mineralization. Biol. Fertil. Soils 36:367-376.

Ekenler, M. and M.A. Tabatabai. 2003. Tillage and residue management effects on beta-glucosaminidase activity in soils. Soil Biol. Biochem. 35:871-874.

Ekenler, M. and M.A. Tabatabai. 2004. Betaglucosaminidase activity as an index of nitrogen mineralization in soils. Commun. Soil Sci. Plant Anal. 35:1081-1094.

Elliott, E.T., I.C. Burke, C.A. Monz, S.D. Frey, K.H. Paustian, H.P. Collins, E.A. Paul, C.V. Cole, R.L. Blevins, W.W. Frye, D.J. Lyon, A.D. Halvorson, D.R. Huggins, R.F. Turco, and M.V. Hickman. 1994. Terrestrial carbon pools: Preliminary data from the corn belt and great plains regions, p. 179-191. In: J.W. Doran, D.C. Coleman, D.F. Bezdicek, and B.A. Stewart (eds.). Defining soil quality for a sustainable environment. Soil Science Society of America, Madison, WI.

Ferris, H., T. Bongers, and R.G.M. de Goede. 2001. A framework for soil food web diagnostics: Extension of the nematode faunal analysis concept. Appl. Soil Ecol. 18:13-29.

Ferris, H. and M.M. Matute. 2003. Structural and functional succession in the nematode fauna of a soil food web. Appl. Soil Ecol. 23:93-110.

Fierer, N., J.A. Jackson, R. Vilgalys, and R.B. Jackson. 2005. Assessment of soil microbial community structure by use of taxon-specific quantitative PCR assays. Appl. Environ. Microbiol. 71:4117-4120. 
Forge, T.A., S. Bittman, and C.G. Kowalenko. 2005. Responses of grassland soil nematodes and protozoa to multi-year and single-year applications of dairy manure slurry and fertilizer. Soil Biol. Biochem. 37:1751-1762.

Forge, T.A., E. Hogue, G. Neilsen, and D. Neilsen. 2003. Effects of organic mulches on soil microfauna in the root zone of apple: Implications for nutrient fluxes and functional diversity of the soil food web. Appl. Soil Ecol. 22:39-54.

Glover, J.D., J.P. Reganold, and P.K. Andrews. 2000. Systematic method for rating soil quality of conventional, organic, and integrated apple orchards in Washington state. Agr. Ecosyst. Environ. 80:29-45.

Goh, K.M., D.R. Pearson, and M.J. Daly. 2001 Effects of apple orchard production systems on some important soil physical, chemical and biological quality parameters. Biol. Agr. Hort. 18:269-292.

Gregorich, E.G., M.H. Beare, U.F. McKim, and J.O. Skjemstad. 2006. Chemical and biological characteristics of physically uncomplexed organic matter. Soil Sci. Soc. Amer. J. 70:975-985.

Griffiths, B.S. 1994. Microbial-feeding nematodes and protozoa in soil: Their effects on microbial activity and nitrogen mineralization in decomposing hotspots and the rhizosphere. Plant Soil 164:25-33.

Heuer, H., M. Krsek, P. Baker, K. Smalla, and E.M.H. Wellington. 1997. Analysis of actinomycete communities by specific amplification of genes encoding 16S rRNA and gel-electrophoretic separation in denaturing gradients. Appl. Environ. Microbiol. 63:323-341.

Horz, H.P., A. Barbrook, C.B. Field, and B.J.M. Bohannan. 2004. Ammonia-oxidizing bacteria respond to multifactorial global change. Proc. Natl. Acad. Sci. USA 101:15136-15141.

Horz, H.P., J.H. Rotthauwe, T. Lukow, and W. Liesack. 2000. Identification of major subgroups of ammonia-oxidizing bacteria in environmental samples by T-RFLP analysis of amoA PCR products. J. Microbiol. Methods 39:197-204.

Ingham, R. 1985. Interactions of bacteria, fungi, and their nematode grazers: Effects on nutrient cycling and plant growth. Ecol. Monogr. 55:119-140.

Ingham, R. 1994. Nematodes, p. 459-490. In: R.W. Weaver, J.S. Angle, and P.J. Bottomley (eds.). Methods of soil analysis, part 2. Microbiological and biochemical properties. Soil Science Society of America, Madison, WI.

Keeney, D.R. and J.M. Bremner. 1966. Comparison and evaluation of laboratory methods of obtaining an index of soil nitrogen availability. Agron. J. 58:498-503.

Kennedy, A.C. 1995. Soil microbial diversity in agricultural systems, p. 249. In: R. Olson, F. Francis, and S. Kaffka (eds.). Exploring the role of diversity in sustainable agriculture. American Society of Agronomy, Madison, WI.

Klose, S., V. Acosta-Martinez, and H.A. Ajwa. 2006. Microbial community composition and enzyme activities in a sandy loam soil after fumigation with methyl bromide or alternative biocides. Soil Biol. Biochem. 38: 1243-1254.

Klose, S. and M.A. Tabatabai. 2000. Urease activity of microbial biomass in soils as affected by cropping systems. Biol. Fertil. Soils 31:191-199.

Knight, T.R. and R.P. Dick. 2004. Differentiating microbial and stabilized $\beta$-glucosidase activity relative to soil quality. Soil Biol. Biochem. 36:2089-2096.

Kramer, S.B., J.P. Reganold, J.D. Glover, B.J.M. Bohannan, and H.A. Mooney. 2005. Reduced nitrate leaching and enhanced denitrifier activity and efficiency in organically fertilized soils. Proc. Natl. Acad. Sci. USA 103:4522-4527.

Krsek, M. and E.M.H. Wellington. 2001. Assessment of chitin decomposer diversity within an upland grassland. Antonie Van Leeuwenhoek 79:261-267

Liu, W.-T., T.L. Marsh, H. Cheng, and L.J. Forney. 1997. Characterization of microbial diversity by determining terminal restriction fragment length polymorphisms of genes encoding $16 \mathrm{~S}$ rRNA. Appl. Environ. Microbiol. 63:45164522.

Mader, P., A. Fliessbach, D. Dubois, L. Gunst, P. Fried, and U. Niggli. 2002. Soil fertility and biodiversity in organic farming. Science 296:1694-1697.

Magid, J., A. Gorissen, and K.E. Giller. 1996. In search of the elusive "active" fraction of soil organic matter: Three size-density fractionation methods for tracing the fate of homogeneously ${ }^{14} \mathrm{C}$-labelled plant materials. Soil Biol. Biochem. 28:89-99.

Magid, J. and C. Kjaergaard. 2001. Recovering decomposing plant residues from the particulate soil organic matter fraction: Size versus density separation. Biol. Fertil. Soils 33:252-257.

Marriott, E.E. and M. Wander. 2006a. Qualitative and quantitative differences in particulate organic matter fractions in organic and conventional farming systems. Soil Biol. Biochem. 38:1527-1536.

Marriott, E.E. and M. Wander. 2006b. Total and labile soil organic matter in organic and conventional farming systems. Soil Sci. Soc. Amer. J. 70:950-959.

Marsh, T.L. 1999. Terminal restriction fragment length polymorphism (T-RFLP): An emerging method for characterizing diversity among homologous populations of amplification products. Curr. Opin. Microbiol. 2:323-327.

Monokrousos, N., E.M. Papatheodorou, J.D. Diamantopoulos, and G.P. Stamou. 2006. Soil quality variables in organically and conventionally cultivated field sites. Soil Biol. Biochem. 38:1282-1289.

Moore, J.M., S. Klose, and M.A. Tabatabai. 2000. Soil microbial biomass carbon and nitrogen as affected by cropping systems. Biol. Fertil. Soils 31:200-210.

Nannipieri, P., E. Kandeler, and P. Ruggiero. 2002. Enzyme activities and microbiological and biochemical processes in soil, p. 1-34. In: R.G. Burns and R.P. Dick (eds.). Enzymes in the environment: Activity, ecology, and applications. Marcel Dekker, New York.

National Organic Program. National Organic Program regulations found at the National Sustainable Agriculture Information Service. 13 July 2006. <http://www.attra.org/organic.html>.

Neher, D.A. 1999. Nematode communities in organically and conventionally managed agricultural soils. J. Nematol. 31:142-154.

Neher, D.A. 2001. Role of nematodes in soil health and their use as indicators. J. Nematol. 35:161-168.

Neher, D.A. and R.K. Olson. 1999. Nematode communities in soils of four farm cropping management systems. Pedobiologia (Jena) 43:430-438

Okano, Y., K.R. Hristova, C.M. Leutenegger, L.E. Jackson, R.F. Denison, B. Gebreyesus, D. Lebauer, and K.M. Scow. 2004. Application of real-time PCR to study effects of ammonium on population size of ammonia-oxidizing bacteria in soil. Appl. Environ. Microbiol. 70:1008.

Oved, T., A. Shaviv, T. Goldrath, R.T. Mandelbaum, and D. Minz. 2001. Influence of effluent irrigation on community composition and function of ammonia-oxidizing bacteria in soil. Appl. Environ. Microbiol. 67:3426-3433.

Parham, J.A. and S.P. Deng. 2000. Detection, quantification and characterization of betaglucosaminidase activity in soil. Soil Biol. Biochem. 32:1183-1190.

Prosser, J.I. 1989. Autotrophic nitrification in bacteria. Adv. Microb. Physiol. 30:125.

Reganold, J.P., J.D. Glover, P.K. Andrews, and H.R. Hinman. 2001. Sustainability of three apple production systems. Nature 410:926-930.

Rutto, K.L., F. Mizutani, D.G. Moon, and K. Kadoya. 2002. The relationship between cultural practices and arbuscular mycorrhizal (AM) activity in orchards under different management systems. J. Jpn. Soc. Hort. Sci. 71: 601-609.

Sanchez, E., H. Khemira, D. Sugar, and T.L. Righetti. 1995. Nitrogen management in orchards, p. 327-380. In: P. Bacon (ed.). Nitrogen fertilization in the environment. Marcel Dekker, New York.

Tabatabai, M.A. 1994. Soil enzymes, p. 775-834. In: R.W. Weaver, J.S. Angle, and P.S. Bottomley (eds.). Methods of soil analysis, part 2. Microbiological and biochemical properties. Soil Science Society of America, Madison, WI.

Tabatabai, M.A. and W.A. Dick. 2002. Enzymes in soil: Research and developments in measuring activities, p. 567-596. In: R.G. Burns and R.P. Dick (eds.). Enzymes in the environment: Activity, ecology, and applications. Marcel Dekker, New York.

Tiedje, J.M., A.J. Sexstone, D.D. Myrold, and J.A. Robinson. 1982. Denitrification: Ecological niches, competition and survival. Antonie Van Leeuwenhoek 48:569-583.

Torsvik, V., J. Goksoyr, and F.L. Daae. 1990. High diversity in DNA of soil bacteria. Appl. Environ. Microbiol. 56:782-787.

Torsvik, V. and L. Ovreas. 2002. Microbial diversity and function in soil: From genes to ecosystems. Curr. Opin. Microbiol. 5:240-245.

Torsvik, V., L. Ovreas, and T.F. Thingstad. 2002. Prokaryotic diversity: Magnitude, dynamics, and controlling factors. Science 296:1064 1066.

van Diepeningen, A.D., O.J. de Vos, G.W. Korthals, and A.H.C. van Bruggen. 2006. Effects of organic versus conventional management on chemical and biological parameters in agricultural soils. Appl. Soil Ecol. 31:120-135.

Wander, M.M. 2004. Soil organic matter fractions and their relevance to soil function, p. 67-102. In: F. Magdoff and R. Weil (eds.). Advances in agroecology. CRC Press, Boca Raton, FL.

Yakovchenko, V.P., L.J. Sikora, and P.D. Millner. 1998. Carbon and nitrogen mineralization of added particulate and macroorganic matter. Soil Biol. Biochem. 30:2139-2146.

Yao, S., I.A. Merwin, G.W. Bird, G.S. Abawi, and J.E. Thies. 2005. Orchard floor management practices that maintain vegetative or biomass groundcover stimulate soil microbial activity and alter soil microbial community composition. Plant Soil 271:377.

Yu, C.P., R. Ahuja, G. Sayler, and K.H. Chu. 2005. Quantitative molecular assay for fingerprinting microbial communities of wastewater and estrogen-degrading consortia. Appl. Environ. Microbiol. 71:1433-1444. 